\title{
Energetic and Exergetic Assessment of the Cooling Efficiency of Automobile Radiator Using Mono and Hybrid Nanofluids
}

\author{
Khalid Faisal Sultan, Hosham Salim Anead, Ameer Abed Jaddoa* \\ Electromechanical. Eng. Dept., University of Technology, Baghdad 00964, Iraq
}

Corresponding Author Email: ameer.a.jaddoa@uotechnology.edu.iq

https://doi.org/10.18280/ijht.390431

Received: 28 February 2021

Accepted: 10 April 2021

\section{Keywords:}

energetic, exergetic, mono nanofluid hybrid nanofluid, cooling efficiency

\begin{abstract}
In this paper, for two separate half-breed Nano liquids, $\mathrm{Ag}(25 \mathrm{~nm})+$ refined water and $\mathrm{Ag}$ $(50 \mathrm{~nm})+\mathrm{Zn}(50 \mathrm{~nm})$-refined water tentatively considered at the vehicle radiator, the execution of restricted convection. Four distinct cross-breed Nano liquid concentrations in the range of 2-6 vol \%. The increase of half breed nanoparticles into the refined water as a base liquid was organized by percentage. Within the range of $201 / \mathrm{min}-60 \mathrm{l} / \mathrm{min}$, the coolant flow rate is altered. Inside the warm trade, Crossover Nano coolants show colossal change compared to the refined water. Ag-refined water cross breed Nano liquid's warm exchange execution was found to be much better than $\mathrm{Ag}+\mathrm{Zn}$-refined water half breed Nano coolant. In addition, with the rise in the concentration of half breed nanoparticle and half breed Nano fluid velocity, the Nusselt number is found to expand. In the advancement of the warm exchange rate, Mono and hybrid nanofluid forms play a very important role in enhancing the heat transfer and refrigeration of car radiators. With an increase in concentration of half-breed nanoparticles for the primary form about 44 percent warm exchange transition, expansion of $6 \mathrm{vol}$ percent crossover nanoparticles were achieved with the rate of warm exchange. In comparison to the current form of cross breed nanoparticles, with an expansion of 6 percent vol concentration, 22 percent extended. The exergy in flow, exergy destruction and exergy efficiency of mono nanofluid $(\mathrm{Ag}+\mathrm{Dw})$ are greater than hybrid nanofluid $(\mathrm{Ag}+\mathrm{Zn}+\mathrm{Dw})$ and distilled water. The exergy inflow, exergy destruction, and exergy efficiency as the concentration of nanoparticles increases for the two forms of mono and hybrid nanofluid. The values parameters of the mono nanofluid $(\mathrm{Ag}+\mathrm{Dw})$ such as exergy in flow, exergy destruction and exergy efficiency at $6 \mathrm{vol} \%$ were $572 \mathrm{~W}, 460 \mathrm{~W}, 72 \%$ respectively while in hybrid nanofluids $(\mathrm{Ag}+\mathrm{Zn}+\mathrm{Dw})$ were $420 \mathrm{~W}, 282 \mathrm{~W}, 51 \%$. The use of mono and hybrid nanofluid as a working fluid results in higher efficiency of heat transfer, which promotes the performance of the car engine and decreases fuel consumption.
\end{abstract}

\section{INTRODUCTION}

Improving the execution of warm trade systems would decrease the use of vitality and present hot exchange upgrade strategies [1-3]. Examined the enhancement of warm exchange with hot geometric variety exchanged using various kinds of balances within different embedded pipes and kinds of external unpleasantness. The aim of attractive field, electric and pulse strategies for warm exchange upgrade of the warm exchanged, Wen \& Ho [4] was examined [5, 6]. Exploratory studied heat transfer of heat exchanged for nano fluids with a litter of 100 nanometers and laminate stream in nano particles. We have gotten the next warm accessibility than fluid wanting a Nano particle [7]. Improve warm accessibility by using Nano liquids for cupric oxide particles to achieve great warm characteristics [8]. In addition to the $\mathrm{H}_{2} \mathrm{O}$ norm on hot exchange disorder transport [9, 10], the advantages of aluminum oxide nanoparticles have been tentatively explored. Inspected research to increases the warm exchange used the nano fluid of the aluminum oxide nanoparticles along with the $\mathrm{H}_{2} \mathrm{O}$ standard and various circumstances. The degree of warm trade for Nano fluid extended almost appears, while atom of Nano fluid particle concentration increases as well as the figure of Reynolds increases [11-13]. Improvements were explored for the warm exchange of heat transport for nanofluid with titanium dioxide nanoparticle refined $\mathrm{H}_{2} \mathrm{O}$. They had gotten a higher degree of warm exchange than the typical liquid for Nano fluid. Convection heat transfer for nanofluids with nanoparticles smaller than $100 \mathrm{~nm}$ and laminar flow was investigated in an experiment. He found that the liquid with nanoparticles had a higher thermal conductivity than the liquid without [14]. To obtain a good thermal property, nanofluids with $\mathrm{CuO}$ particles were used to improve thermal conductivity [15]. The effects of oxide nanoparticles $\mathrm{Al}_{2} \mathrm{O}_{3}$ with a water base on turbulence convection heat transfer were investigated experimentally. Duangthongsuk \& Wongwises [16-18] looked at how a nanofluid with a nanoparticle of $\mathrm{TiO}_{2}-$ distilled water could improve convection heat transfer. They achieved this by using a nanofluid with a higher heat transfer coefficient than the base fluid.

The aims of this paper are to assess the performance improvement of energy and exergy through mono and hybrid nanofluid inlet and outlet temperature and efficiency of exergy. In addition, multiple variables have been tested that could affect the improvement of the mono nanofluid $(\mathrm{Ag},+\mathrm{Dw})$ and hybrid nanofluid $(\mathrm{Ag}+\mathrm{Zn}+\mathrm{Dw})$ coefficient of heat transfer 
including the size of nanoparticles, volume fraction, number of Reynolds, and temperature of mono and hybrid nanofluids.

\section{PREPARATION OF THE HYBRID NANOFLUID AS COOLANT}

The mono and hybrid Nano fluids test arrangements are arranged by scattering pre-weighed volumes of dry silver Particles in refined water. At that point, the blends were applied to Ultra-sonic blending $[150 \mathrm{kHz}, 500 \mathrm{Watt}$ at $25-30 \mathrm{o}$ $\mathrm{C}$, and that for time $2 \mathrm{~h}$ for separate molecule totals at Toshiba, Britain]. Half-breed nanofluid containing processed $\mathrm{H}_{2} \mathrm{O}$ with half-breed nanoparticles of a material. The pictures of crossover mono and hybrid nanofluid planning are shown in Figure 1.

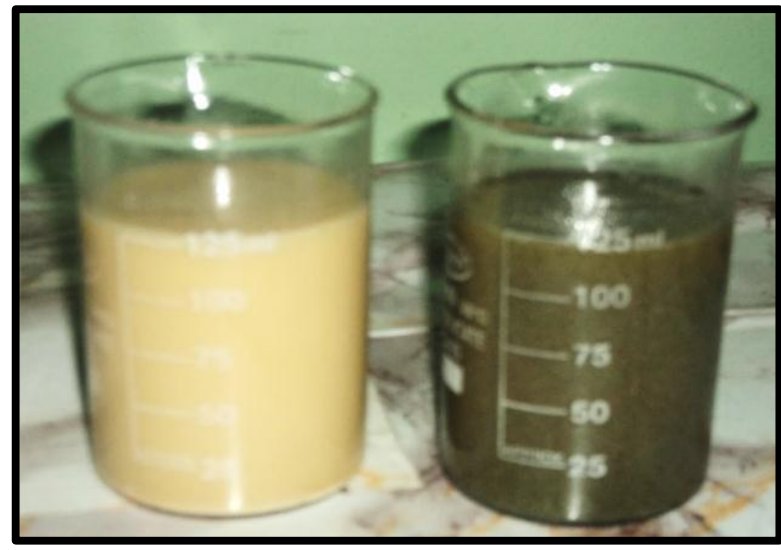

Figure 1. Mono nanofluid silver $\mathrm{Ag}(25 \mathrm{~nm})$ and hybrid nanofluid silver Ag (50nm) and Zinc Zn (50nm)

\section{EXPERIMENTAL METHODS}

The unit used in the tests consists of the after-take and appears in Figure 2. The pump offers a 20-60 litter/minute shifting stream average. Tank Pipes for Cooling, to maintain the temperature between 40 and $80^{\circ} \mathrm{C}$, an electrical radiator was used to steam the working fluid and controls were used. Flow meter style Dwyer arrangement MMA lower than expected-Ace stream meter used with the accuracy of $0.41 /$ min to degree mass stream rate easily. Forced Fan Draft, The Globe valve was used in the rig to direct the stream rate. Thermocouples ((K-kind) used at the gulf and heater outlet as well as eight thermocouples (K-kinds). Such thermocouples were mounted along the test area and placed in the middle of the radiator surfaces. Radiator (a warm cross stream exchanger), as shown in Figure 3. Due to the simple investigation of the internal warm exchange, the pace and temperature discussions are steady within the experiments. Radiator characteristics as shown in Table 1.

Table 1. Radiator determinations are tabulated.

\begin{tabular}{cc}
\hline Kind of fins and pipe & Aluminum \\
\hline Distance of raditor & $320 \times 20 \times 382.4 \mathrm{~m}$ meter \\
Finform & Corugaed \\
Heat transfer area & 1.25 Squer meter \\
Part size & 4.75 Squer meter \\
Size of fins & 1.14 Liter \\
\hline
\end{tabular}

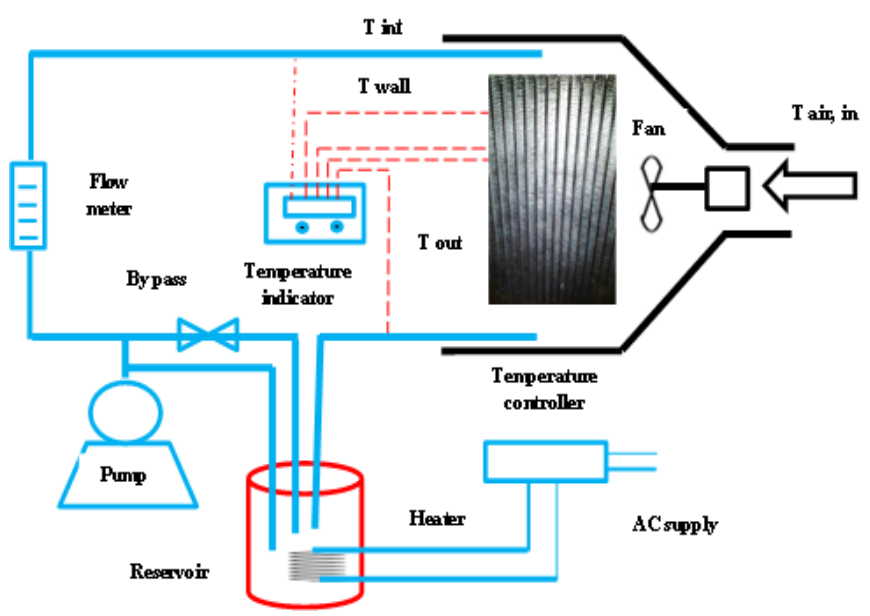

Figure 2. Schematic of experimental setup

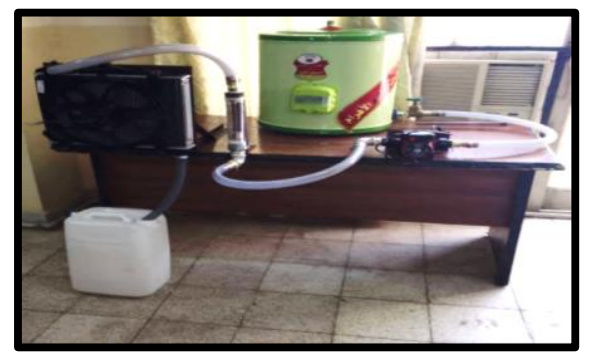

Figure 3. Experimental setup

\section{DATA PREPARING OF HYBRID NANO FLUID}

The taking after strategy to get warm exchange coefficient and comparing Nusselt number has been done. Agreeing to Newton's law of cooling:

$$
\mathrm{Q}=\mathrm{hADT}=\mathrm{hA}\left(\mathrm{T}_{\mathrm{b}}-\mathrm{Tw}\right)
$$

warm exchange rate can be calculated as takes after:

$$
\mathrm{Q}=\mathrm{m} \operatorname{Cp} \Delta \mathrm{T}=\mathrm{mCp}(\mathrm{Tin}, \mathrm{nf}-\mathrm{Tout}, \mathrm{nf})
$$

with respect to the uniformity of $\mathrm{Q}$ in the above equations:

$$
\mathrm{Nu}_{\mathrm{hb}, \mathrm{nf}}=\frac{\mathrm{h}_{\mathrm{ex}} \mathrm{D}_{\mathrm{h}}}{k_{n f}}=\frac{\dot{m} \mathrm{Cp}(\text { Tin, } \mathrm{nf}-\text { Tout, nf }) \mathrm{D}_{\mathrm{h}}}{k_{, n f}}
$$

Improvement of warm exchange amidst situation of crossover Nano liquid and standard liquid situation is characterized as:

$$
\text { Enhancement }=\frac{\mathrm{Nu}_{\mathrm{nf}}-\mathrm{Nu}_{\mathrm{bf}}}{\mathrm{Nu} u_{\mathrm{nf}}} \times 100
$$

The loss of energy is estimated as [19]. Exergy loss= Exergy Inflow-Exergy outflow

$$
E_{x L}=E_{x i}-E_{x 0}
$$

The tube exergy inflow is shown below.

$$
E x_{i n f}=\dot{m}_{n f} \operatorname{Cp} p_{n f}\left[\left(\mathrm{~T}_{\mathrm{nf} 1}-\mathrm{T}_{\mathrm{a}}\right)-\mathrm{T}_{\mathrm{a}}\left(\ln \frac{\mathrm{T}_{\mathrm{nf} 1}}{\mathrm{~T}_{\mathrm{a}}}\right)\right]
$$


The tube exergy outflow is described below.

$$
E x_{\text {onf }}=\dot{m}_{n f} \operatorname{Cp}_{\mathrm{nf}}\left[\left(\mathrm{T}_{\mathrm{nf} 2}-\mathrm{T}_{\mathrm{a}}\right)-\mathrm{T}_{\mathrm{a}}\left(\ln \frac{\mathrm{T}_{\mathrm{nf} 2}}{\mathrm{~T}_{\mathrm{a}}}\right)\right]
$$

Exergy efficiency is determined as:

$$
\begin{gathered}
\text { Exergy Efficiency }=\frac{\text { Exergy inflow }- \text { Exergy loss }}{\text { Exergy inflow }} \\
\text { Exergy Efficiency }=1-\frac{\text { Ex L }}{\text { Exi }}
\end{gathered}
$$

\section{RESULTS AND DISCUSSION}

Using base distilled water as the working fluid, the heat transfer coefficients are experimentally measured before obtaining those of distilled water ( $\mathrm{Ag}$ and $\mathrm{Ag}+\mathrm{Zn}$ ) nanofluids to verify the accuracy and reliability of the experimental system, as shown in Figure 4. There was a difference between three well-known empirical associations [20-23] and the experimental results. Just in Figure 5 there is fairly good agreement between the Gnielinsky equation and the measurements used in this analysis over the Reynolds number range. The dimensionless thermal properties of the two mono and hybrid nanofluids $(\mathrm{Ag}+\mathrm{Dw})$ and $(\mathrm{Ag}+\mathrm{Zn}+\mathrm{Dw})$ compared to those of distilled water are shown in Figure 6-7. These Figures showed that, with increasing concentrations of mono and hybrid nanoparticles, density, thermal conductivity and viscosity increased, with growing concentrations of mono and hybrid nanoparticles, the real heat declined. Owing to the scale of mono nanoparticles and silver thermal conductivity, the thermal conductivity of mono nanofluids $(\mathrm{Ag}+\mathrm{Dw})$ was greater than that of hybrid nanofluids $(\mathrm{Ag}+\mathrm{Zn}+\mathrm{Dw})$. For the two forms of mono and hybrid nanofluids $(\mathrm{Ag}+\mathrm{Dw})$ and $(\mathrm{Ag}$ $+\mathrm{Zn}+$ Dw), Figure 8-13 display the impact of the Reynolds number, volume fraction of nanoparticles and inlet temperature of fluid on the Nusselt number. As a consequence of an increase in the fluid's energy transfer with an increase in the volume fraction, the velocity components of the mono and hybrid nanofluid increase. The sensitivity to the volume fraction of nanoparticles of the thermal boundary layer thickness is related to an increased thermal conductivity. Higher values of thermal conductivity are actually accompanied by higher values of the thermal diffusivity. The high thermal diffusivity value makes it possible for the temperature gradients to drop and thus increases the thickness of the boundary layer [24]. The Nusselt number is decreased by this increase in thermal boundary layer thickness; The Nusselt number, however, is a multiplication of the temperature gradient and the ratio of thermal conductivity. As the decrease in the temperature gradient due to the presence of nanoparticles is much lower than the thermal conductivity ratio, the amount of Nusselt is therefore increased by increasing the volume fraction of the nanoparticles. The addition of nanoparticles to the coolant therefore has the potential to improve cooling rates for automotive and heavyduty engines or to remove engine heat with a cooling system of reduced size. To understand the effect of the temperature on the thermal efficiency of the radiator, different fluid inlet temperatures for each concentration have been applied. For the two forms of mono and hybrid nanofluids $(\mathrm{Ag}+\mathrm{Dw})$ and $(\mathrm{Ag}$ $+\mathrm{Zn}+\mathrm{Dw})$, the mono and hybrid nanofluid inlet temperatures include $45^{\circ} \mathrm{C}, 65^{\circ} \mathrm{C}$, and $75^{\circ} \mathrm{C}$. These Figures display that an increase in the inlet temperature of mono and hybrid nanofluid marginally increases the amount of Nusselt due to an increase in the effect of test mono and hybrid nanofluid radiation on the inner wall of the tubes. These statistics also indicate that with the rise in Reynolds number, the Nusselt number increases. The enhancement of the heat transfer between the case of mono and hybrid nanofluid and the case of base fluid is classified as [25]:

$$
\text { Enhancement } \%=\frac{\mathrm{Nu}(\mathrm{nf})-\mathrm{Nu}(\mathrm{bf})}{\mathrm{Nu}(\mathrm{bf})} \times 100
$$

Figures 13-18 show the effects of the Reynolds number, nanoparticle volume fraction and mono and hybrid nanofluid inlet temperature on heat transfer enhancement. Through the increase in mono and hybrid nanoparticle concentrations, Reynolds number and mono and hybrid nanofluid inlet temperature, the increase in heat transfer has increased. It is evident for the distilled water-based mono and hybrid nanofluid that the improvement increases with the number of Reynolds and the impact of the number of Reynolds is pronounced at higher concentrations of mono and hybrid nanoparticle. Due to the size of mono nanoparticles and silver thermal conductivity, the increase in heat transfer for mono nanofluid $(\mathrm{Ag}(25 \mathrm{~nm})+\mathrm{Dw})$ was greater than hybrid nanofluid $(\mathrm{Ag}(50 \mathrm{~nm})+\mathrm{Zn}(25 \mathrm{~nm})+\mathrm{Dw})$. The findings showed that the improvement ratios when the temperature of the mono nanofluid ( $\mathrm{Ag}+$ distilled water) $45^{\circ} \mathrm{C}, 65^{\circ} \mathrm{C}, 75^{\circ} \mathrm{C}$, and the concentration 6 vol\% were $10.8 \%, 14.34 \%, 20.21 \%$ respectively, While the improvement ratios were for (Ag $(50 \mathrm{~nm})+\mathrm{Zn}(50 \mathrm{~nm})+\mathrm{Dw}) 5.32 \%, 8.21 \%, 12.11 \%$. The results indicated that the improvement ratios when the temperature of the mono nanofluid ( $\mathrm{Ag}+$ distilled water) $45^{\circ} \mathrm{C}$, $65^{\circ} \mathrm{C}, 75^{\circ} \mathrm{C}$, and the concentration 2 vol $\%$ were $4.1 \%, 8.31 \%$, $10.21 \%$ respectively. While the improvement ratios were for $(\mathrm{Ag}(50 \mathrm{~nm})+\mathrm{Zn}(50 \mathrm{~nm})+\mathrm{Dw}) 2.22 \%, 5.13 \%, 7.10 \%$. Figure 19-24 indicated that the exergy in flow, exergy destruction and exergy efficiency of mono nanofluid $(\mathrm{Ag}+\mathrm{Dw})$ are greater than hybrid nanofluid $(\mathrm{Ag}+\mathrm{Zn}+\mathrm{Dw})$ and distilled water. With increasing nanoparticle concentration, the exergy inflow, exergy degradation, and exergy efficiency for the two forms of mono and hybrid nanofluid increase. he values parameters of the mono nanofluid $(\mathrm{Ag}+\mathrm{Dw})$ such as exergy in flow, exergy destruction and exergy efficiency at $6 \mathrm{vol} \%$ were 572 $\mathrm{W}, 460 \mathrm{~W}, 72 \%$ respectively while in hybrid nanofluids $(\mathrm{Ag}+$ $\mathrm{Zn}+\mathrm{Dw}$ ) were $420 \mathrm{~W}, 282 \mathrm{~W}, 51 \%$.

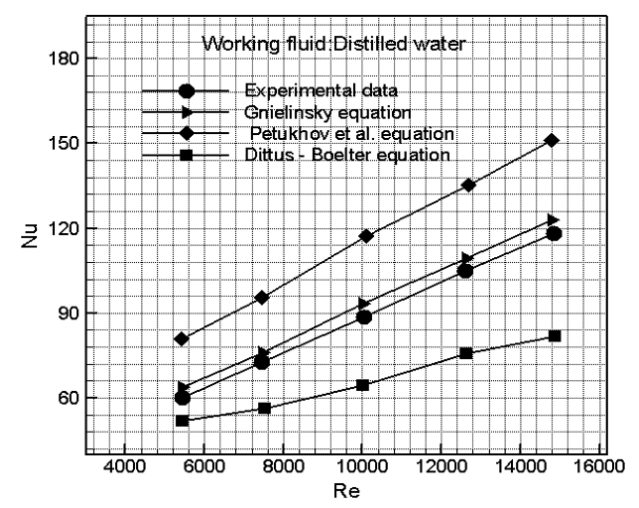

Figure 4. Comparison of distilled water experimental findings with previous study results 


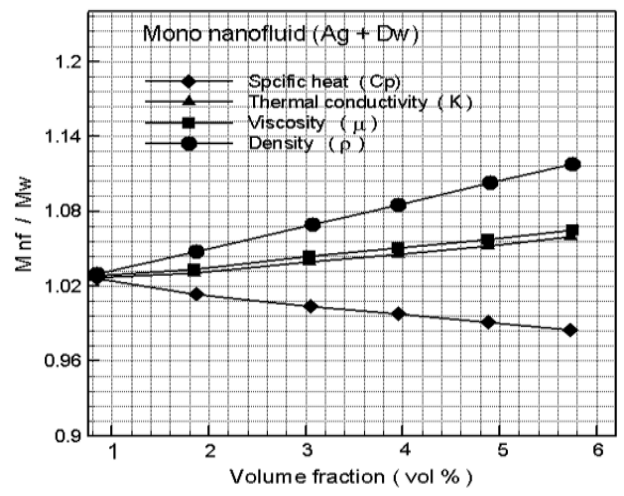

Figure 5. Dimensionless thermal properties of Mono nanofluid $(\mathrm{Ag}+\mathrm{Dw})$

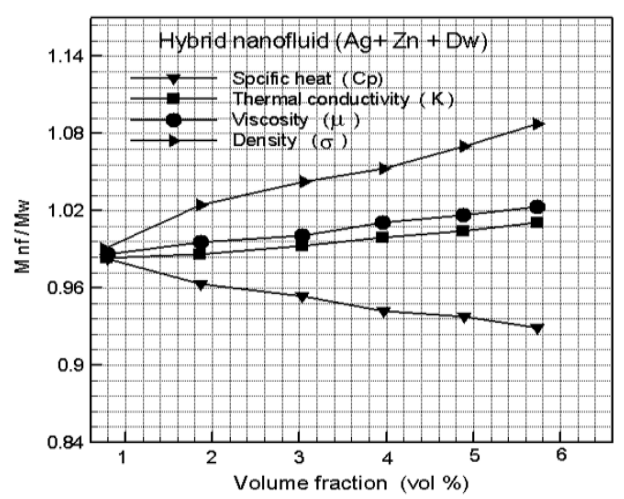

Figure 6. Hybrid nanofluid $(\mathrm{Ag}+\mathrm{Zn}+\mathrm{Dw})$ dimensionless thermal properties

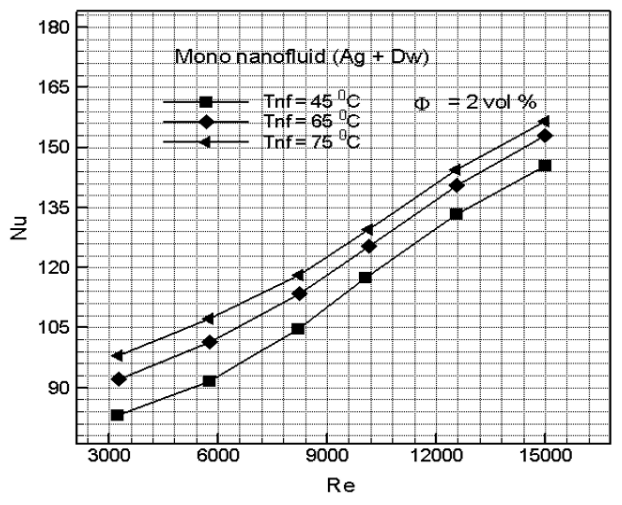

Figure 7. Nu number versus Reynolds number at $\Phi=4$ vol $\%$ for $(\mathrm{Ag}+\mathrm{Dw})$

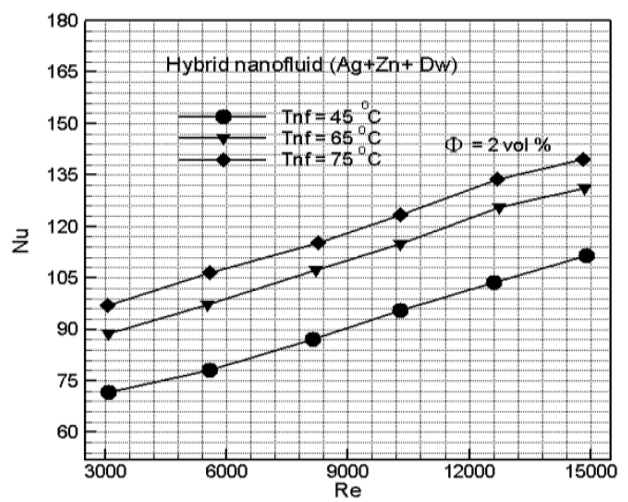

Figure 8. Nu number versus Re number at $\Phi=4$ vol \% for $(\mathrm{Ag}+\mathrm{Zn}+\mathrm{Dw})$

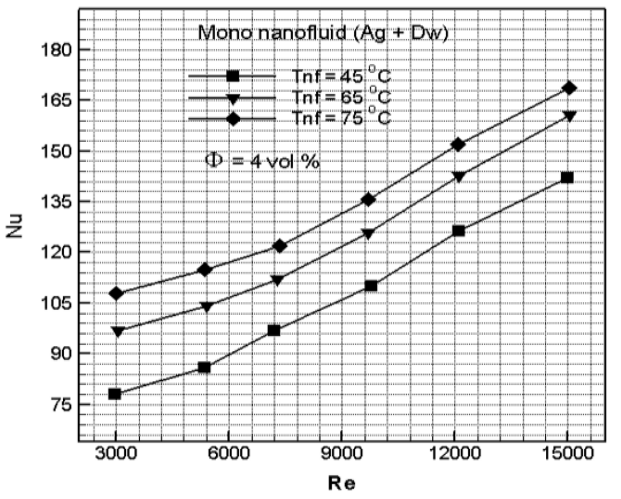

Figure 9. $\mathrm{Nu}$ number versus Reynolds number at $\Phi=4$ vol\% for $(A g+D w)$

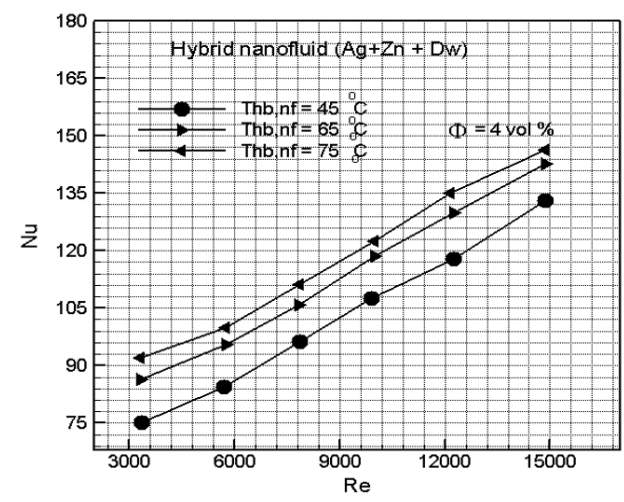

Figure10. Nu number versus Re number at $\Phi=4$ vol \% for $(\mathrm{Ag}+\mathrm{Zn}+\mathrm{Dw})$

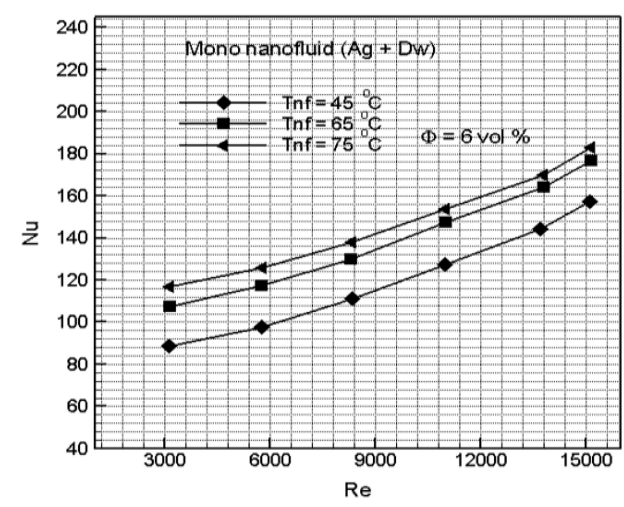

Figure 11. Nu number versus Reynolds number at $\Phi=6$ vol $\%$ for $(\mathrm{Ag}+\mathrm{Dw})$

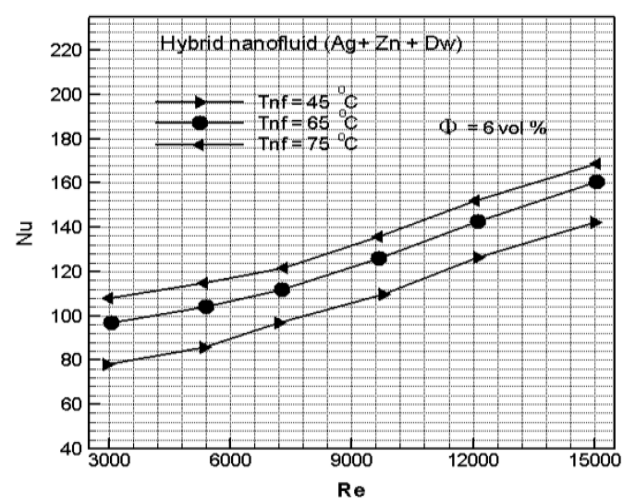

Figure 12. Nu number versus Re number at $\Phi=6$ vol $\%$ for $(\mathrm{Ag}+\mathrm{Zn}+\mathrm{Dw})$ 


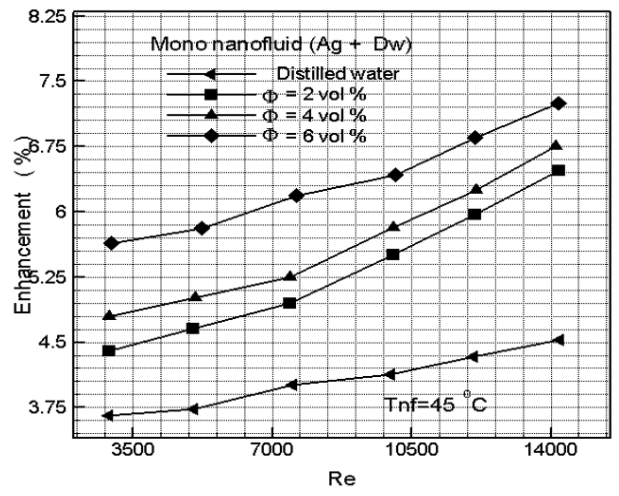

Figure13. Enhancement versus Re at different $\Phi$ for $(\mathrm{Ag}+$ Dw)

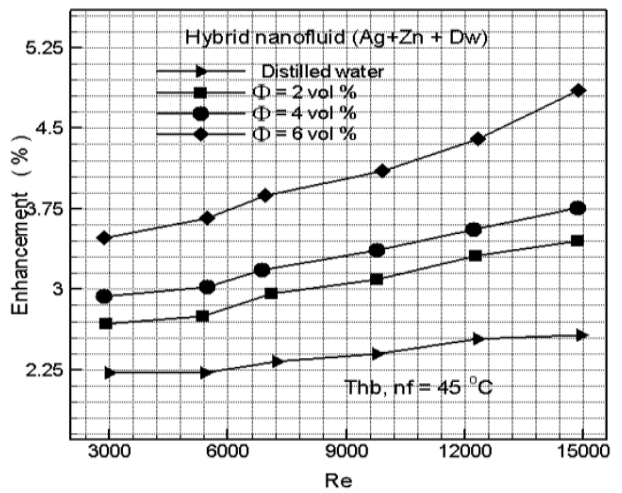

Figure 14. Enhancement ver sus Re at different $\Phi$ for $(\mathrm{Ag}+$ $\mathrm{Zn}+\mathrm{Dw})$

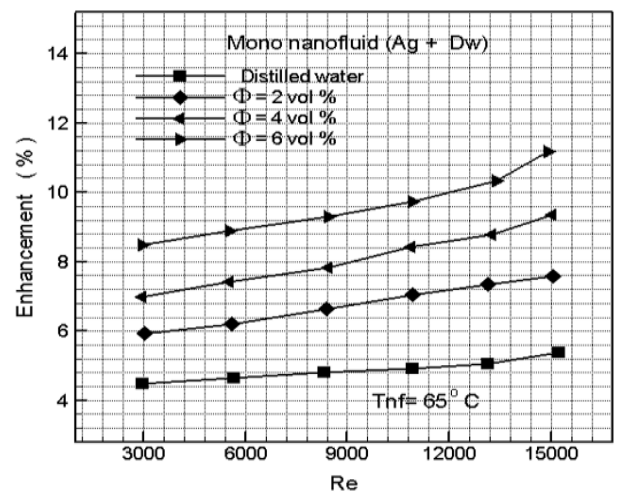

Figure15. Enhancement versus $\mathrm{Re}$ at different $\Phi$ for $(\mathrm{Ag}+$ Dw)

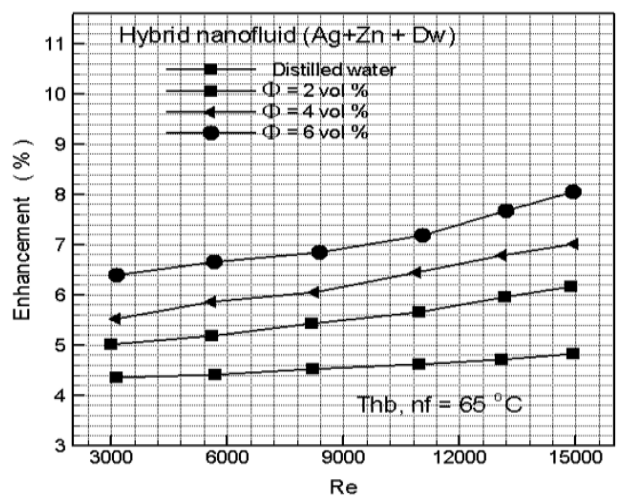

Figure 16. Enhancement versus Re at different $\Phi$ for $(\mathrm{Ag}+$ $\mathrm{Zn}+\mathrm{Dw}$ )

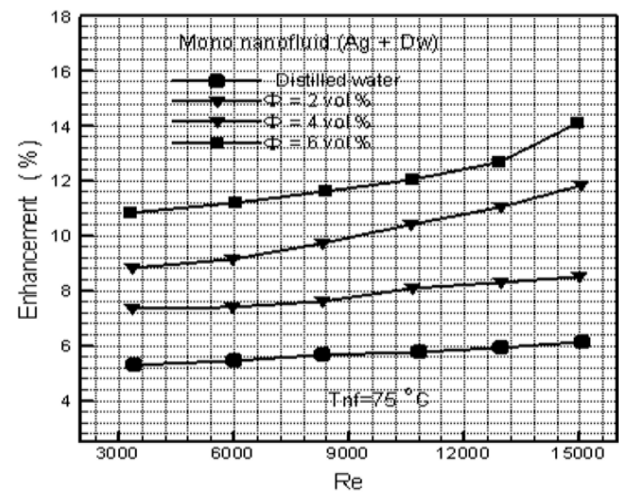

Figure 17. Enhancement versus Re at different $\Phi$ for $(\mathrm{Ag}+$ Dw)

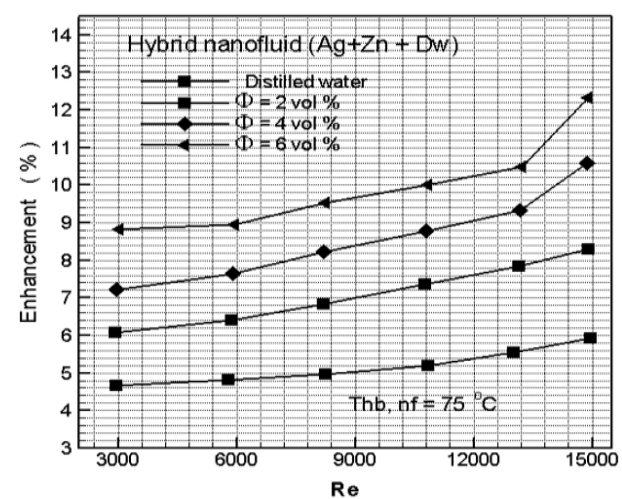

Figure 18. Enhancement versus Re at different $\Phi$ for $(\mathrm{Ag}+$ $\mathrm{Zn}+\mathrm{Dw}$ )

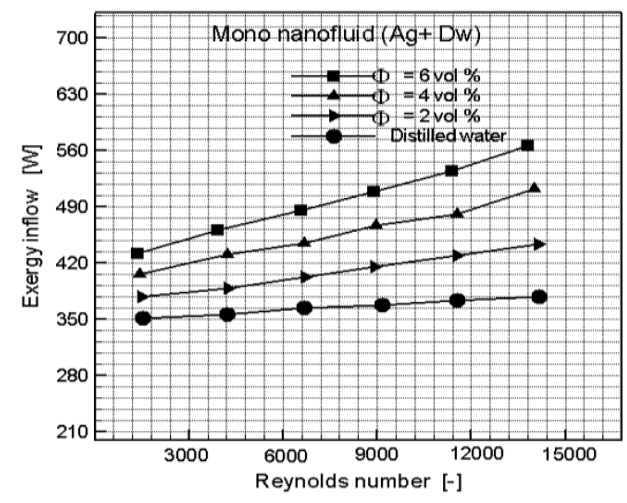

Figure 19. Exergy inflow of mono nanofluid $(\mathrm{Ag}+\mathrm{Dw})$ at different $\Phi$

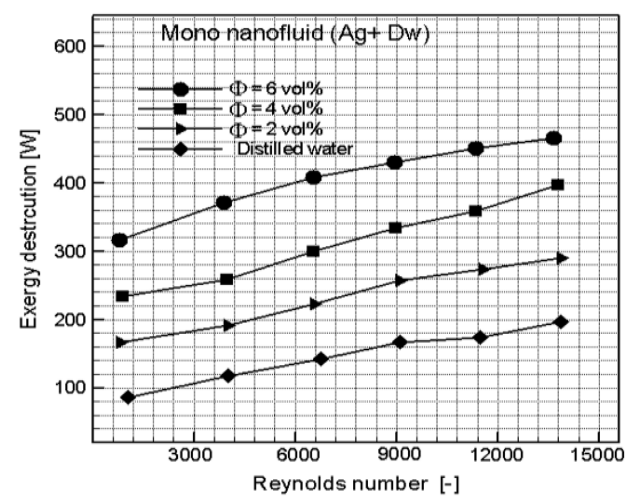

Figure 20. Exergy inflow of hybrid nanofluid $(\mathrm{Ag}+\mathrm{Zn}+\mathrm{Dw})$ at different $\Phi$ 


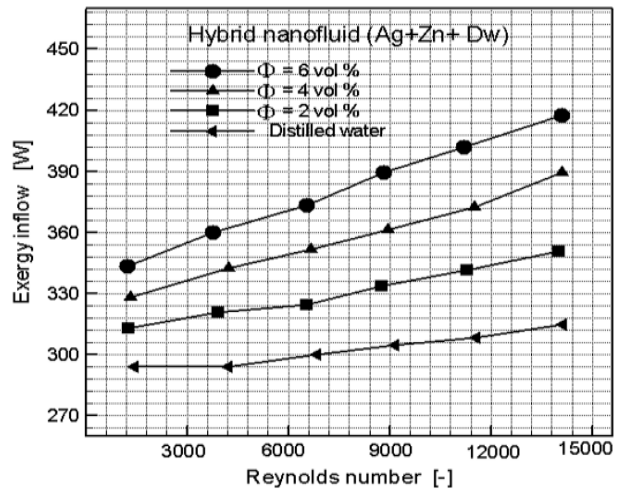

Figure 21. Exergy destruction of mono nanofluid $(\mathrm{Ag}+\mathrm{Dw})$ at different $\Phi$

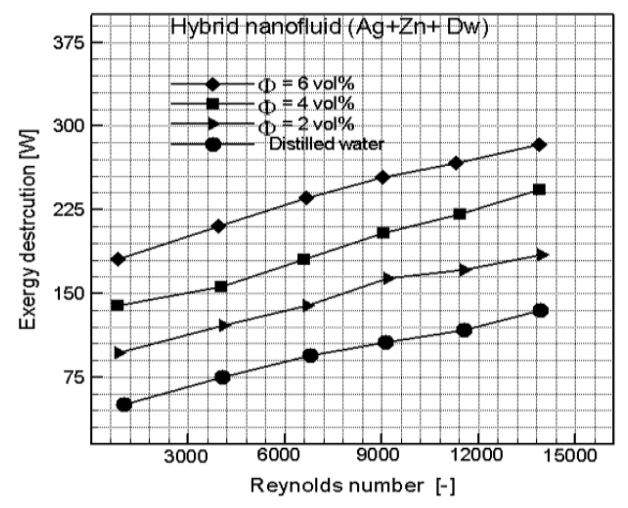

Figure 22. Exergy destruction of hybrid nanofluid $(\mathrm{Ag}+\mathrm{Zn}+$ Dw) at different $\Phi$

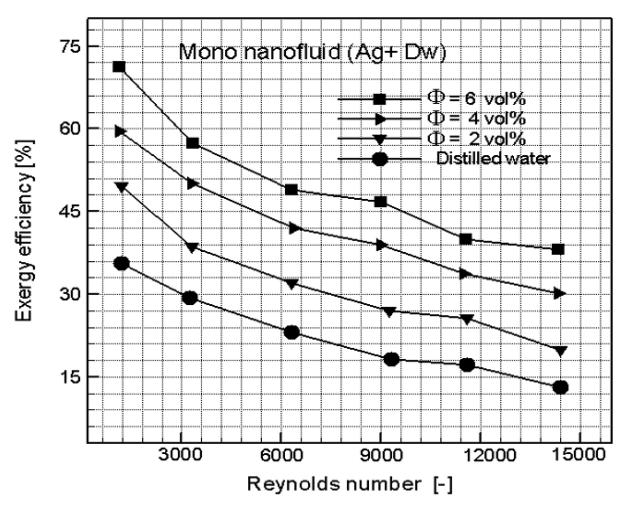

Figure 23. Exergy efficiency of mono nanofluid $(\mathrm{Ag}+\mathrm{Dw})$ at different $\Phi$

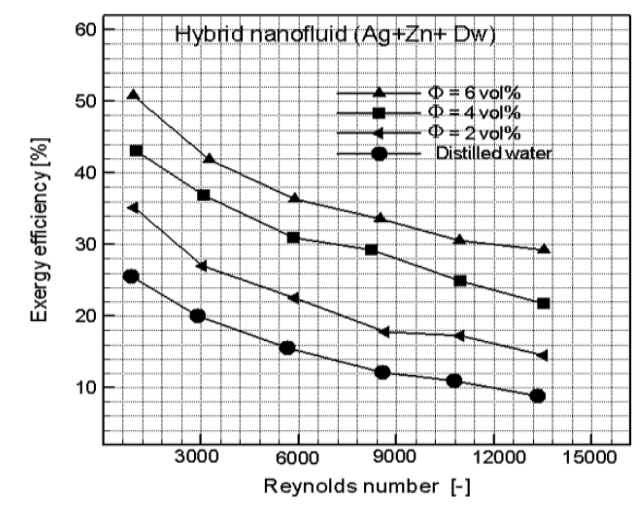

Figure 24. Exergy efficiency of hybrid nanofluid $(\mathrm{Ag}+\mathrm{Zn}+$ Dw) at different $\Phi$

\section{CONCLUSION}

The summary results from used two types of mono and hybrid nano fluids are much as follows:

1) Mono and hybrid nanofluid forms play a very important role in enhancing the heat transfer and refrigeration of car radiators.

2) The thermal conductivity of the silver is due to the size of nanoparticles and, the heat transfer increase for the mononanofluid (Ag $(25 \mathrm{~nm})+\mathrm{Dw})$ was greater than hybrid nanofluid $(\mathrm{Ag}(50 \mathrm{~nm})+\mathrm{Zn}$ $(50 \mathrm{~nm})+\mathrm{Dw})$. A decrease in the temperature gradients is caused by the high value of thermal diffusivity and the boundary layer thickness increases accordingly.

3) The use of mono and hybrid nanofluid as a working fluid results in higher efficiency of heat transfer, which promotes the performance of the car engine and decreases fuel consumption.

4) With the increase of mono and hybrid nanofluid inlet temperature, fraction of nanoparticle volume and number of Reynolds, the number of Nusselt increased.

5) Owing to the nanoparticles size and the thermal conductivity of silver, the thermal conductivity for mono nanofluids $(\mathrm{Ag}+\mathrm{Dw})$ was greater than for hybrid nanofluids $(\mathrm{Ag}+\mathrm{Zn}+\mathrm{Dw})$.

6) The exergy in flow, exergy destruction and exergy efficiency of mono nanofluid $(\mathrm{Ag}+\mathrm{Dw})$ are greater than hybrid nanofluid $(\mathrm{Ag}+\mathrm{Zn}+\mathrm{Dw})$ and distilled water.

7) With increasing nanoparticle concentration, the exergy inflow, exergy degradation, and exergy efficiency for the two forms of mono and hybrid nanofluid increase.

\section{REFERENCES}

[1] Tijing, L.D., Pak, B.C., Baek, B.J., Lee, D.H. (2006). A study on heat transfer enhancement using straight and twisted internal fin inserts. International Communications in Heat and Mass Transfer, 33(6): 719726.

https://doi.org/10.1016/j.icheatmasstransfer.2006.02.00 6

[2] Naphon, P. (2006). Effect of coil-wire insert on heat transfer enhancement and pressure drop of the horizontal concentric tubes. International Communications in Heat and Mass Transfer, 33(6): 753-763. https://doi.org/10.1016/j.icheatmasstransfer.2006.01.02 0

[3] Sahin, B., Demir, A. (2008). Performance analysis of a heat exchanger having perforated square fins. Applied Thermal Engineering, 28(5-6): 621-632. https://doi.org/10.1016/j.applthermaleng.2007.04.003

[4] Wen, M.Y., Ho, C.Y. (2009). Heat-transfer enhancement in fin-and-tube heat exchanger with improved fin design. Applied Thermal Engineering, 29(5-6): 1050-1057. https://doi.org/10.1016/j.applthermaleng.2008.05.019

[5] Hashemabadi, S.H., Etemad, S.G. (2006). Effect of rounded corners on the secondary flow of viscoelastic fluids through non-circular ducts. International Journal of Heat and Mass Transfer, 49(11-12): 1986-1990. https://doi.org/10.1016/j.ijheatmasstransfer.2006.01.014 
[6] Zhang, Z., Xu, T., Fang, X. (2004). Experimental study on heat transfer enhancement of a helically baffled heat exchanger combined with three-dimensional finned tubes. Applied Thermal Engineering, 24(14-15): $2293-$ 2300 .

https://doi.org/10.1016/j.applthermaleng.2004.01.012

[7] Hashemabadi, S.H., Etemad, S.G., Naranji, M.G., Thibault, J. (2003). Laminar flow of non-Newtonian fluid in right triangular ducts. International Communications in Heat and Mass Transfer, 30(1): 5360. https://doi.org/10.1016/S0735-1933(03)00007-1

[8] Yakut, K., Sahin, B. (2004). Flow-induced vibration analysis of conical rings used for heat transfer enhancement in heat exchangers. Applied Energy, 78(3): 273-288

https://doi.org/10.1016/j.apenergy.2003.09.001

[9] Laohalertdecha, S., Wongwises, S. (2006). Effects of EHD on heat transfer enhancement and pressure drop during two-phase condensation of pure R-134a at high mass flux in a horizontal micro-fin tube. Experimental Thermal and Fluid Science, 30(7): 675-686. https://doi.org/10.1016/j.expthermflusci.2006.01.003

[10] Paschkewitz, J.S., Pratt, D.M. (2000). The influence of fluid properties on electrohydrodynamic heat transfer enhancement in liquids under viscous and electrically dominated flow conditions. Experimental Thermal and Fluid Science, 21(4): 187-197. https://doi.org/10.1016/S0894-1777(00)00002-9

[11] Umeda, N., Takahashi, M. (2000). Numerical analysis for heat transfer enhancement of a lithium flow under a transverse magnetic field. Fusion Engineering and Design, 51: 899-907. https://doi.org/10.1016/S09203796(00)00424-5

[12] Wen, D., Ding, Y. (2004). Experimental investigation into convective heat transfer of nanofluids at the entrance region under laminar flow conditions. International journal of Heat and Mass Transfer, 47(24): 5181-5188. https://doi.org/10.1016/j.ijheatmasstransfer.2004.07.012

[13] Liu, M.S., Lin, M.C., Huang, I.T., Wang, C.C. (2006). Enhancement of thermal conductivity with $\mathrm{CuO}$ for nanofluids. Chemical Engineering \& Technology: Industrial Chemistry-Plant Equipment-Process Engineering-Biotechnology, 29(1): 72-77. https://doi.org/10.1002/ceat.200500184

[14] Pak, B.C., Cho, Y.I. (1998). Hydrodynamic and heat transfer study of dispersed fluids with submicron metallic oxide particles. Experimental Heat Transfer an International Journal, 11(2): 151-170. https://doi.org/10.1080/08916159808946559

[15] Heris, S.Z., Etemad, S.G., Esfahany, M.N. (2006). Experimental investigation of oxide nanofluids laminar flow convective heat transfer. International Communications in Heat and Mass Transfer, 33(4): 529535. https://doi.org/10.1016/j.icheatmasstransfer.2006.01.00 5

[16] Duangthongsuk, W., Wongwises, S. (2009). Heat transfer enhancement and pressure drop characteristics of $\mathrm{TiO}_{2}$-water nanofluid in a double-tube counter flow heat exchanger. International Journal of Heat and Mass Transfer, 52(7-8): 2059-2067. https://doi.org/10.1016/j.ijheatmasstransfer.2008.10.023
[17] Duangthongsuk, W., Wongwises, S. (2010). An experimental study on the heat transfer performance and pressure drop of $\mathrm{TiO}_{2}$-water nanofluids flowing under a turbulent flow regime. International Journal of Heat and Mass Transfer, 53(1-3): 334-344. https://doi.org/10.1016/j.ijheatmasstransfer.2009.09.024

[18] Arora, N., Gupta, M. (2020). An updated review on application of nanofluids in flat tubes radiators for improving cooling performance. Renewable and Sustainable Energy Reviews, 134: 11-20. https://doi.org/10.1016/j.rser.2020.110242

[19] Sarkar, J., Ghosh, P., Adil, A. (2015). A review on hybrid nanofluids: Recent research, development and applications. Renewable and Sustainable Energy Reviews, 43: 164-177. https://doi.org/10.1016/j.rser.2014.11.023

[20] Ho, C.J., Huang, J.B., Tsai, P.S., Yang, Y.M. (2010). Preparation and properties of hybrid water-based suspension of $\mathrm{Al}_{2} \mathrm{O}_{3}$ nanoparticles and MEPCM particles as functional forced convection fluid. International Communications in Heat and Mass Transfer, 37(5): 490494. https://doi.org/10.1016/j.icheatmasstransfer.2009.12.00 7

[21] Dittus, F.W., Boelter, L.M.K. (1930). Heat Transfer in Automobile Radiators of Tubular Type, pp. 443-461. Berkeley: University California. Publ. Eng., 2, 13.

[22] Gnielinski, V. (2002). Wärmeübertragung in Rohren, VDI-Wämeatlas, pp. 295-302.

[23] Petukhov, B.S. (1970). Heat transfer and friction in turbulent pipe flow with variable physical properties. In Advances in Heat Transfer, 6: 503-564. https://doi.org/10.1016/S0065-2717(08)70153-9

[24] Kandasamy, R., Mat Isa, N., Ashwin Kumar, E.N. (2015). Impact of heat transfer on MHD boundary layer of copper nanofluid at a stagnation point flow past a porous stretching and shrinking surface with variable stream conditions. ARPN Journal of Science and Technology, 5(5): 219-231

[25] Sultan, K.F., Farge, T.Z., Ail, S.H. (2015). Experimental study of heat transfer enhancement in car radiator by using copper and aluminum nanofluids. Eng. \&Tech. Journal.

\section{NOMENCLATURE}

\begin{tabular}{|c|c|c|}
\hline Symbol & Quantity & units \\
\hline $\mathrm{Q}$ & Thermal energy & $\mathrm{J}$ \\
\hline $\mathrm{h}$ & heat transfer coefficient & $\mathrm{W} / \mathrm{m}^{2} \mathrm{k}$ \\
\hline A & peripheral area & $\mathrm{m}^{2}$ \\
\hline $\mathrm{Cp}$ & Specific heat & $\mathrm{J} / \mathrm{kg} \mathrm{k}$ \\
\hline$\dot{m}$ & Mass flow rate & $\mathrm{kg} / \mathrm{s}$ \\
\hline Tw & Wall Temperature & ${ }^{\circ} \mathrm{C}$ \\
\hline $\mathrm{Tb}$ & Bulk temperature & ${ }^{\circ} \mathrm{C}$ \\
\hline $\mathrm{Ta}$ & Ambit temperature & ${ }^{\circ} \mathrm{C}$ \\
\hline $\mathrm{D}_{\text {hy }}$ & hydraulic diameter & $\mathrm{m}$ \\
\hline $\mathrm{knf}$ & $\begin{array}{l}\text { Thermal conductivity of } \\
\text { nanofluid }\end{array}$ & $\mathrm{W} / \mathrm{m}^{2} \mathrm{~K}$ \\
\hline $\mathrm{Nu}$ & Nusselt number & - \\
\hline ExL & Exergy loss & $\overline{\mathrm{W}}$ \\
\hline $\mathrm{Ex}_{\mathrm{i}}$ & Exergy inlet & W \\
\hline
\end{tabular}

